\title{
Bering Strait: a linguistic area bridging two continents
}

\author{
Lawrence D. Kaplan
}

\section{OpenEdition}

Journals

Édition électronique

URL : https://journals.openedition.org/jsa/16760

DOI : 10.4000/jsa. 16760

ISSN : 1957-7842

Éditeur

Société des américanistes

\section{Édition imprimée}

Date de publication : 15 juin 2019

Pagination : $175-180$

ISBN : 978-2-902715-11-4

ISSN : 0037-9174

Référence électronique

Lawrence D. Kaplan, "Bering Strait: a linguistic area bridging two continents », Journal de la Société des américanistes [En ligne], 105-1 | 2019, mis en ligne le 17 juin 2019, consulté le 04 septembre 2022. URL : http://journals.openedition.org/jsa/16760 ; DOI : https://doi.org/10.4000/jsa.16760 


\title{
Bering Strait: a linguistic area bridging two continents
}

\author{
Lawrence D. KAPLAN *
}

Michèle Therrien's work has taken a wide view of Inuit culture, includes the physical world, and looks at relationships with the spiritual world along with the Inuit universe in general, through language and metaphor. Works like Le corps inuit talk about wider relationships of vocabulary with different parts of the Inuit world, including the kayak, other conveyances, and the snow house, for example. For Therrien the Inuit world is a broad system composed of elements linked to one another, closely in some cases and more distantly in others, but always connected. A key element of this system is language, based on individual words, which take on larger and more important meanings in conjunction with other words, forming a sort of body that may be compared with the physical human body, which is also a complex system lending itself to projection and metaphor.

En langue inuit, le mot est un assemblage, une construction formée d'éléments stables et mobiles. Sa structure semble voisine de celle du corps: comme le corps, le mot est ferme et concentré, se divise longitudinalement (radical et affixes), possède des éléments périphériques (racine et désinence), une extériorité (contexte de l'énoncé), une intériorité (nature du radical modifiée par la qualité de l'affixe); le mot évolue, connaît l'involution et s'inscrit dans la temporalité, comme le corps il est susceptible d'expressivité, de projection (métaphore). Les mots-corps sont actifs, influent sur le réel, comme la dénomination ne laisse pas le corps indifférent. (Therrien 1987, p. 170)

With Therrien's view of the Inuit cosmos and its complex interrelationships in mind, I will present the linguistic situation of the Bering Strait region, where the existence of a linguistic area attests to contact among a number of Inuit languages and dialects. A linguistic area or Sprachbund is found where a group of languages have common features due to diffusion through language contact. These socalled areal features may be shared among related or unrelated languages, so long as the similarities are the result of contact rather than genetic relationship.

* Alaska Native Language Center [ldkaplan@alaska.edu]. 
The languages under consideration here are all of the Eskimo-Aleut family and thus exhibit many common characteristics because of this genetic relationship; other shared features appear to result from proximity and contact and would be considered areal features. My emphasis here is on Inupiaq, although a fuller discussion of the subject would include more Yupik data, showing how these languages are involved in the areal spread of features. There are also likely to be linguistic features that have spread beyond the Eskimo-Aleut family, notably to Chukotko-Kamchatkan and more specifically to Chukchi and perhaps Koryak, but these connections are beyond the scope of this paper.

The languages under consideration here are Inupiaq (on Alaska's Seward Peninsula and neighboring islands), Central Alaskan Yupik (mostly found south of Inupiaq on the Seward Peninsula in the Norton Sound area and through much of Southwest Alaska), and Central Siberian Yupik (found on St. Lawrence Island, Alaska, and across the Bering Sea on the nearby coast of Siberia). The latter two languages belong to the Yupik branch of the language family, and Inupiaq belongs to the Inuit branch. I use the designation "Bering Strait region" as it is used in northwest Alaska to mean the Seward Peninsula and the area around Norton Sound, in addition to the immediate vicinity of Bering Strait itself. This region is unique in the Inuit world in terms of the number of Inuit and Yupik languages found in close proximity whose populations have been in contact with each other for quite a long period. Although these languages and dialects have retained their unique identities, their history of co-existence in this region has resulted in areal features that are clearly a result of contact and not of genetic relationship (see Figure 1).

\section{Shared features}

Prosodic phenomena are found throughout the region and are especially prominent throughout the Yupik branch, where all languages exhibit processes of syllable adjustment, although precise rules differ according to language and dialect. Central Alaskan Yupik, for example, lengthens short vowels in alternating syllables and geminates single consonants before a long vowel or vowel pair (Jacobson 1995, p. 8-10). Central Siberian Yupik, on the other hand, lengthens short vowels in alternate syllables but lacks the so-called rule of automatic gemination before long vowels (Jacobson 2008, p. xxix-xxxii). The Inuit branch typically has no prosodic-type rules, except in the Bering Strait region adjacent to several Yupik languages, making it appear that these processes exist in Inupiaq because of the influence of Yupik. The Inupiaq rules differ from what is found in Yupik, since Inupiaq adjusts consonants in alternating syllables. (See Kaplan 1985 for a discussion of King Island Inupiaq phonology, which exemplifies Bering Strait Inupiaq.) 


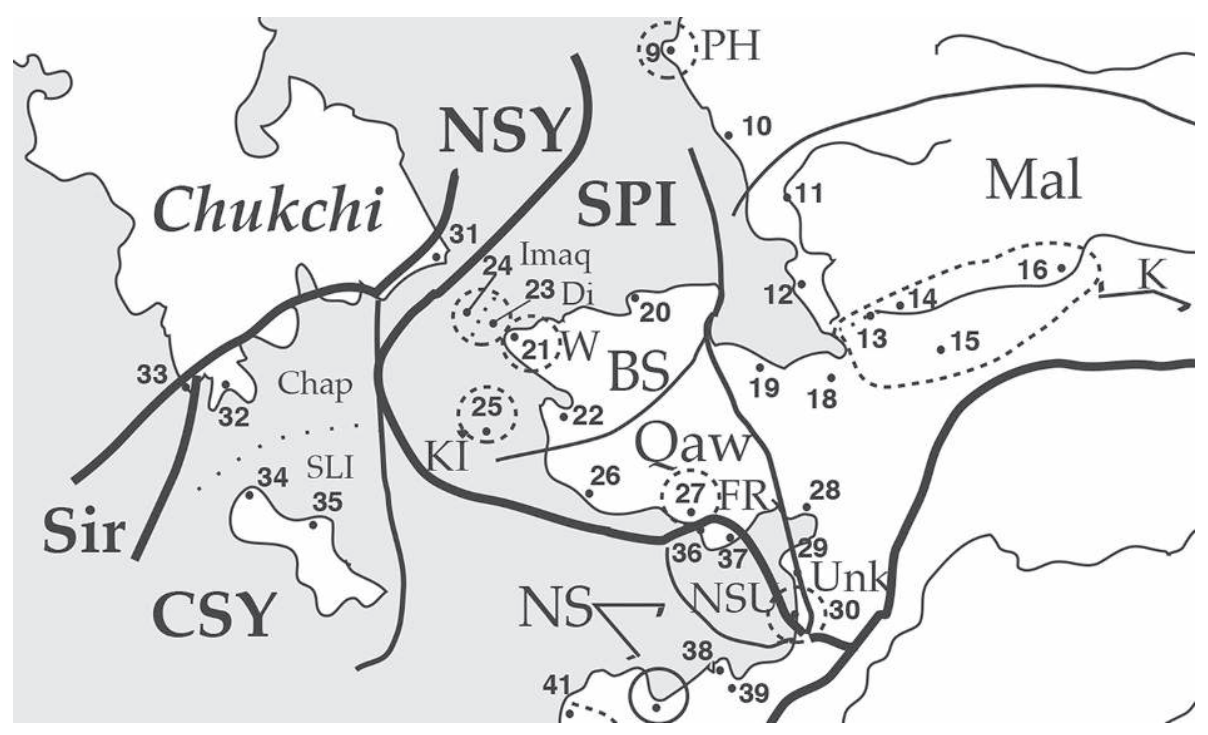

Fig. 1- Eskimo-Aleut languages and dialects of Alaska and Siberia (adapted from Fortescue, Jacobson and Kaplan 2010, map 2).

Inupiaq dialects:

$\mathrm{NAI}=$ North Alaskan Inupiaq; NS = North Slope; Mal = Malimiut; SPI = Seward Peninsula Inupiaq; Qaw $=$ Qawiaraq; FR = Fish River; I = Igloo; Unk = Unalakleet; BS = Bering Strait; Di = Diomede; $\mathrm{KI}=$ King Island; $\mathrm{W}=$ Wales-Shishmaref. Yupik languages and dialects:

$\mathrm{AAY}=$ Alaskan Alutiiq Yupik; $\mathrm{C}=\mathrm{Chu-}$ gach; $\mathrm{K}=$ Koniag; CAY = Central Alaskan
Yupik; GCY = General Central Yupik; NS $=$ Norton Sound; NSK = Norton SoundKotlik; NSU = Norton Sound-Unaliq; CSY = Central Siberian Yupik; Chap = Chaplinski; SLI $=$ St. Lawrence Island; NSY = Naukan Siberian Yupik.

Other:

Sir $=$ Sirenikski.

Note that although no other Inuit dialects have a similarly productive process that operates on alternating syllables, Eastern Canadian Inuktitut does have Schneider's Law, which sets up a pattern of alternation between closed and open syllables, also a process of syllable adjustment (Rose, Pigott, and Wharram 2012). I have earlier suggested (Kaplan 1985) that Schneider's Law could be the remnant of a widespread process in Inuit, and Rose, Pigott, and Wharram have entertained the same possibility. Even if there was an old phonological rule of syllable adjustment in Inuit, the most elaborate surviving version is found near Bering Strait in the vicinity of Yupik languages, which maintain prosodic phenomena as a productive part of their phonology.

The following King Island Inupiaq examples illustrate the process of consonant gradation, which lenites and deletes consonants in alternate syllables. 
The prosodic pattern is set in the first syllable of the word and affects alternate syllables throughout the word. Final syllables are not affected, and the process begins anew with the next phonological word.

\begin{tabular}{|c|c|c|c|c|c|c|}
\hline /naniq & - & $q a q$ & - & tugut/ & $\rightarrow$ & naniqaatuyut \\
\hline "lamp" & "have" & & & $\begin{array}{c}\text { we (1 } 1^{\text {st }} \text {-person } \\
\text { plural intransitive) }\end{array}$ & & "We have a lamp." \\
\hline man:ik & - & $q a q$ & - & tugut & $\rightarrow$ & man:isaqtu:t \\
\hline "egg" & "have" & & & $\begin{array}{c}\text { we (1 }\left(1^{\text {st }} \text {-person }\right. \\
\text { plural intransitive) }\end{array}$ & & "We have an egg." \\
\hline
\end{tabular}

The suffix -qaq "have" exhibits two allomorphs, -qaa and - $a q q$, whose occurrence is governed by the stems naniq and mannik, where the short $n$ in the former and long $n$ : in the latter produce different results further down the word. (For a full account of this phenomenon, see Kaplan 1985, 2009.)

A further phonological phenomenon involves the so-called fourth vowel shwa (a), which is found in all Yupik languages, reflecting Proto Eskimo (PE) *ə, but is generally not found in Inupiaq, since there has been a merger, largely with $i$, except in Seward Peninsula dialects, where phonetic traces of $\partial$ are still found. The most prominent occurrences of shwa are in Diomede Inupiaq, e.g. abvaq "bowhead whale" and anə "house," which are generally asviq and ini in all other Inupiaq dialects. Most likely, this "fourth vowel" is retained from the proto language under the influence of nearby Yupik, particularly neighboring Naukan Yupik, which lies just across Bering Strait to the west of the Diomede Islands. In other Bering Strait Inupiaq dialects, shwa may be present occasionally but not consistently as in Diomede. Areal phenomena appear to be operating here, with three adjacent Yupik languages causing the retention of the shwa vowel.

An example of a lexical item that appears in the Bering Strait area is * macas, the PE word for "sun," which is macaq in Norton Sound Central Yupik and mazaq in King Island Inupiaq, among its various reflexes. (This stem is found in related forms in dialects out of this area, but only around Bering Strait is it the primary word for "sun.")

Inupiaq words for "dog" also have a special geographical distribution, since most dialects from North Alaskan Inupiaq east use some form of qipmiq, qimmiq, etc., from the PE * qіkтів. Seward Peninsula Inupiaq dialects have qimugin or qimugun for "dog," parallel to Central Yupik qimuxta "dog, lit. one that pulls." (Central Siberian Yupik and Naukan Yupik use forms of PE * qіkmis, see Jacobson 2004, 2008, 2012.)

As to morphology, languages and dialects distant from this region construct words for big, small, long, short, etc., by adding inflectional suffixes directly to a verb stem, e.g. Central Yupik ay:uq and North Alaskan Inupiaq ayiřuq 
"it is big" as well as mik:uq and mikiruq "it is small." In the Bering Strait area, a circumlocution is required, adding the copular suffix to yield constructions that mean something like "it is a big one" or "it is a small one," e.g. King Island Inupiaq miksru:řauruq (from miksruuraq "small thing") or Central Siberian Yupik məkəsta:Xa:yuq "it is small," lit. "it is a small one" from məkəsta:Xaq "small thing," all based upon the PE stem *mikə- "to be small."

\section{Conclusion}

It is difficult to determine the time depth of these areal linguistic relationships found among the languages in the vicinity of Bering Strait, but the causation is by and large not recent. Relatively recent borrowings and contact phenomena between Yupik and Inupiaq can be identified in areas where the two languages are still in close contact; many speakers of Fish River Qawiaraq, for example, have largely replaced $s$ with $\check{c}$, which must be borrowed from Unaliq Central Yupik, with which there has been much bilingualism. There are undoubtedly other similarities among these languages beyond what is presented here and more similarities yet if non-Inuit languages in Siberia are taken into account.

Contact among the various groups that inhabit the area around Bering Strait has been ongoing for quite a long time, and linguistic evidence of these contacts therefore comes as no surprise. Trade, warfare, and intermarriage have all been documented in this region, along with the sharing of territory as mentioned above for Fish River Inupiaq. For a period of at least a couple of centuries, Central Yupik and Inupiaq have co-existed on the Seward Peninsula, with Inupiaq people moving south and east through the Norton Sound area, gradually replacing Unaliq Yupik with Inupiaq. Today it is English that dominates the Alaskan side of Bering Strait, threatening the continued survival of all the indigenous languages located there.

\section{References cited}

Fortescue Michael, Steven Jacobson, and Lawrence KaPlan

2010 Comparative Eskimo dictionary with Aleut cognates, Alaska Native Language Center, Fairbanks, [2 $2^{\text {nd }}$ ed.].

JACOBSON Steven A.

2012 Yup'ik Eskimo dictionary, Alaska Native Language Center, Fairbanks, [2 ${ }^{\text {nd }}$ ed.].

2008 St. Lawrence Island/Siberian Yupik Eskimo dictionary, Alaska Native Language Center, Fairbanks, vols. I and II.

2004 Naukan Yupik Eskimo dictionary (English), Alaska Native Language Center, Fairbanks.

1995 A practical grammar of the Central Alaskan Yup'ik Eskimo language, Alaska Native Language Center, Fairbanks. 
KAPLAN Lawrence

2009 "Seward peninsula Inupiaq and language contact around bering strait," in Marc-Antoine Mahieu, and Nicole Tersis (eds.), Variations on polysynthesis. The Eskimo-Aleut languages, John Benjamins, Amsterdam, p. 261-272.

1985 "Seward peninsula consonant gradation and its relationship to prosody," in Michael Krauss (ed.), Yupik Eskimo prosodic systems. Descriptive and comparative studies, Alaska Native Language Center (Alaska Native Language Center research papers, 7), Fairbanks, p. 191-210.

Rose Yvan, Paul Pigott, and Douglas Wharram

2012 "Schneider's law revisited: the syllable-level remnant of an older metrical rule," in Proceedings of phonology in the 21st century. In honour of Glyne Piggott, McGill Working Papers in Linguistics, Montreal, p. 1-12.

Therrien Michèle

1987 Le corps inuit. Québec arctique, Société anthropologique et linguistique de France (SELAF)/Presses universitaires de Bordeaux (Arctique, 1), Paris. 